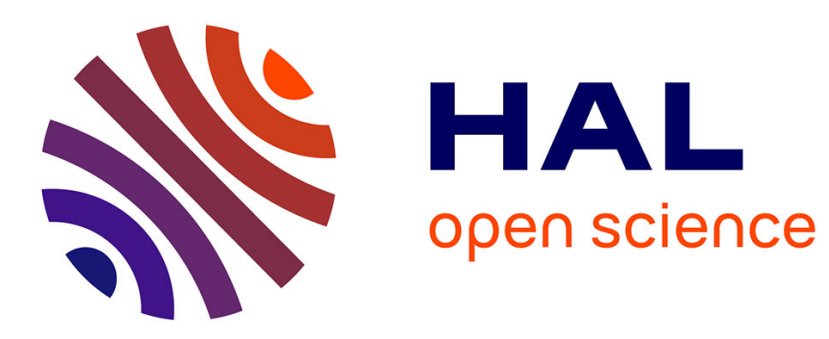

\title{
Chemical vapour deposition of nitride and oxynitride dielectric films
}

S. Alexandrov

\section{To cite this version:}

S. Alexandrov. Chemical vapour deposition of nitride and oxynitride dielectric films. Journal de Physique IV Proceedings, 1993, 03 (C3), pp.C3-465-C3-465. 10.1051/jp4:1993364 . jpa-00251421

\section{HAL Id: jpa-00251421 https://hal.science/jpa-00251421}

Submitted on 1 Jan 1993

HAL is a multi-disciplinary open access archive for the deposit and dissemination of scientific research documents, whether they are published or not. The documents may come from teaching and research institutions in France or abroad, or from public or private research centers.
L'archive ouverte pluridisciplinaire HAL, est destinée au dépôt et à la diffusion de documents scientifiques de niveau recherche, publiés ou non, émanant des établissements d'enseignement et de recherche français ou étrangers, des laboratoires publics ou privés. 


\title{
Chemical vapour deposition of nitride and oxynitride dielectric films
}

\author{
S.E. ALEXANDROV
}

Department of Electronic Material Technology, St. Petersburg State Technical University, Polytechnical Str. 19, St. Petersburg 195 251, Russia

\section{ABSTRACT}

VLSI device design rules as well as compound semiconductor device manufacture require dielectric films of different properties and higher quality than traditional silicon based materials.

Nitrides and oxynitrides of aluminium, gallium and germanium exhibit useful and often excellent combinations of electrical, optical, chemical and thermomechanical properties, and therefore there has been a growing interest in the deposition of these thin films. The oxynitrides, which can be described as a solid solution between a nitride and an oxide, have attracted special attention because by precise control of operating conditions it is possible to change the film composition and therefore the main physical and chemical properties over a wide range. As a result, it is often possible to achieve combinations of material characteristics which are impossible to obtain either for pure nitride or oxide.

In the last two decades CVD including, different forms such as plasma enhanced and photo assisted CVD, has become a dominating deposition technique for the formation of thin dielectric layers. These types of film deposition processes are complicated from a physicochemical point of view and for successful applications in industry it would be highly desirable to have a fundamental understanding of the process mechanisms.

The purpose of this paper is to review the preparation and characterisation of thin dielectric films of nitrides and oxynitrides of aluminium, gallium and germanium by the technique of CVD using "halogen" containing precursors. Special attention will be paid to results obtained from the study of the kinetics of the deposition, including those from mass spectroscopy and direct IR spectroscopy of the gas phase during CVD of nitride and oxynitride films, and to the influence of the deposition conditions on the structure, composition and basic properties of the films.

The potential applications of nitride and oxynitride films in semiconductor device technology will also be reviewed. 